\title{
Green Human Resource Management, Employment and Social Corporate Responsibility in Asia
}

Irfan Novianto K,Bambang Hadi Prabowo

(STIE Jaya Negara Tamansiswa Malang)

\begin{abstract}
This study aims to investigate the quality level of green human resource management, employment and corporate social responsibility in Asia. Collecting data in this study using interviews with 200 employees in 12 multi-national companies in Asia by random sampling using the LinkedIn application then quantifying for regression using the autoregression moving average model. The interview aims to extract data in the form of quality levels of green human resource management, employment and corporate social responsibility. We find that there is a positive relationship between corporate social responsibility quality level of green human resource management and employment.
\end{abstract}

Keywords: Green Human Resource Management, Employment, Corporate Social Responsibility

\section{Background}

The development of human resource management is very rapid in the Asian continent. Asian economic development is very fast with China and India having very good economic growth (Wu,2012). Good economic growth in the Asian continent is also accompanied by business and economic uncertainty with economic diversity between countries across the Asian continent (Hsiao \& Hsiao, 2017). Asia is a continent with a diversity of inhabitants, not only racial or ethnicdiversity but also cultural diversity and social perspectives including religion. This diversity can be both an opportunity and a threat. Diversity can be a strength that can be used together in the common interest. However, without tolerance and mutual understanding will be a threat or a challenge in itself. Human resource management in Asia is very concerned about managing the diversity of human resources, especially in multi-national companies (Francine,2017). Diversity of human resources requires management that respects and understands each other so that it can make diversity a unifying and enormous strength to be used in the common interest to achieve common goals. Asia is a unique continent with all the diversity in it. Managing people in Asia must also manage the environment and culture around the company so that there is a management synergy between environmentally friendly human resource management, known as green human resource management, employment and corporate social responsibility (Dainty \& Loosemore,2013).

\section{Literature Review}

Human resource management in managing the diversity of human resources can use a group psychological approach so that in the long term groups of employees who work together can form the 
same bond in the organization. This group's psychological approach serves to build mutual strength through diversity and mutual respect and understanding of common goals so that mutual bonds are formed in achieving common goals. When a social group realizes that there are common interests and goals, a sense of mutual help and cooperation can be formed so that social forces or social capital are formed in completing work to achieve common goals (Werner,2021).

Social capital can be built and developed not only among employees or company stakeholders but also society and consumers. So that a sense of social responsibility is formed in a corporate environment that can foster social capital. This corporate social responsibility can be used as a means to establish communication and mutual understanding between the company and the community and employees. This can have an impact on the emergence of mutual solidarity and minimize the risk of conflict in the business environment (Lerbinger,2018). Social capital and a comfortable working environment are indispensable for multi-national companies. Because multinational companies will inevitably meet with cultural and ethnic diversity in the organizational environment. Including the community around the company. Therefore, social capital is needed to be built inside and outside the company. Communication between the head office and branch offices or subsidiaries in remote areas must be carried out properly. So that the working relationship can be well established. In multi-national companies in Asia, there is a close relationship between green human resource management, employment and corporate social responsibility (O'Toole \& Mayer,2013).

\section{Research Method}

Collecting data in this study using interviews with 200 employees in 12 multi-national companies in Asia by random sampling using the LinkedIn application, then quantifying for regression using the autoregression moving average model. The interview aims to extract data in the form of quality levels of green human resource management, employment and corporate social responsibility. We use average data or all the data obtained is averaged based on a group of variables determined based on literature review and their background and time series, that we perform regression using the moving average model autoregression method with the following equation:

$\mathrm{CSR}_{\mathrm{t}}=\mathrm{C}_{\mathrm{t}}+\beta_{1} \mathrm{E}_{\mathrm{t} 1}+\beta_{2} \mathrm{GHRM}_{2}+\mathrm{e}_{\mathrm{t}}$

Where,

CSR = Corporate Social Responsibility

$\mathrm{E}=$ employment

GHRM = Quality level of green human resource management

$\mathrm{e}=$ Term Error

We calculate CSR based on the CSR index by using the following calculations: Corporate Social Responsibility fund budget divided by company profits in a period of one year with the following equation:

$\mathrm{CSR}=\mathrm{CSRB} / \mathrm{CI}$

Where CSR is the CSR index. CSRB is a Corporate Social Responsibility budget. And, CI is the company's advantage. Our workforce calculates the following: average employee income divided by company profits divided by total employees, with the following equation: 
$\mathrm{E}=\mathrm{S} /(\mathrm{CI} / \mathrm{N})$

Where $\mathrm{E}$ is employment, $\mathrm{CI}$ is the company's profit. $\mathrm{N}$ is the total employees. We calculate the GHRM by dividing the total environmental cases that have been resolved by the company by the condition that if there has never been an environmental case, it will be added by 1 . With the following equation:

$\mathrm{GHRM}=\mathrm{CS} / \mathrm{TC}$, if $\mathrm{TC}=0$, then $\mathrm{GHRM}=1$. Where $\mathrm{CS}$ is the total environmental cases that have been resolved. And, TC is the total environmental case facing the company.

\section{Result and Discussion}

The estimation results are as follows:

$\mathrm{CSR}=-0.0417905623788+0.617323852618 * \mathrm{E}+0.409825468649 * \mathrm{GHRM}$

From the estimation results, employment (E) and the level of quality of green human resource management (GHRM) have a positive effect on Corporate Social Responsibility (CSR). Where every $1 \%$ increase in the level of Corporate Social Responsibility is followed by an increase in employment of $0.6 \%$ and a level of quality of green human resource management of $0.4 \%$ which is briefly described in Table 1 illustrates the estimation results as follows:

Table 1. Estimation Results

\begin{tabular}{|l|l|l|l|l|}
\hline Variable & Coefficient & Std. Error & t-Statistic & Prob. \\
\hline C & -0.041791 & 0.100751 & -0.414792 & 0.6835 \\
\hline E & 0.617324 & 0.211414 & 2.919978 & 0.0095 \\
\hline GHRM & 0.409825 & 0.221318 & 1.851748 & 0.0815 \\
\hline R-squared & $7.87 \mathrm{E}-01$ & Mean dependent var & 0.71 \\
\hline Adjusted R-squared & 0.761951 & S.D. dependent var & 0.141049 \\
\hline S.E. of regression & 0.068818 & Akaike info criterion & -2.377221 \\
\hline Sum squared resid & 0.080511 & Schwarz criterion & -2.227861 \\
\hline Log likelihood & 26.77221 & Hannan-Quinn criter. & -2.348064 \\
\hline F-statistic & 31.40776 & Durbin-Watson stat & 1.924514 \\
\hline Prob(F-statistic) & 0.000002 & \\
\hline
\end{tabular}

Based on the estimation results described in Table 1. Corporate Social Responsibility reflects employment (E) and the quality level of green human resource management (GHRM). The following is a forecasting of Corporate Social Responsibility in Asia from 2000 to 2019 in figure 1 as follows:

Figure 1. Forecasting Results of Corporate Social Responsibility in Asia

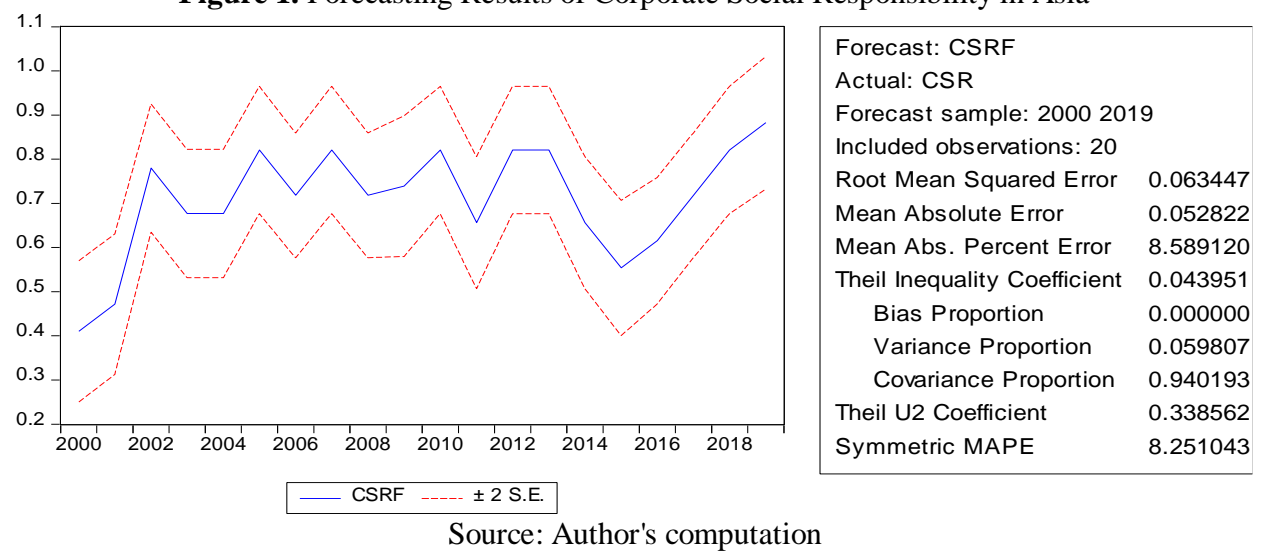


Based on the forcasting results in Figure 1, the development of employee job satisfaction levels in Asia tends to fluctuate according to work conditions. This proves that human resource management is important for protecting the environment and for the sustainability of the company.

\section{Conclusion}

Corporate social responsibility has an impact on environmental sustainability, community satisfaction with the company and minimizes economic inequality and opportunity in the community. This certainly has an impact on increasing consumption and community loyalty to the company which has an impact on the company's business growth.

\section{Reference:}

Dainty,A., Loosemore,M.(2013).Human Resource Management in Construction Projects. London: Routledge

Francine,S.(2017).Diversity, dialogue and sharing: online resources for a more resourceful world. Paris : UNESCO Publishing

Hsiao,F.S.T., Hsiao,M.C.W.(2017).Economic Development of Emerging East Asia: Catching Up of Taiwan and South Korea. New York: Anthem Press

Lerbinger,O.(2018).Corporate Communication: An International and Management Perspective. Hoboken : John Wiley and Sons

O'Toole,J., Mayer,D.(2013).Good Business: Exercising Effective and Ethical Leadership. London: Routledge

Wu,Y.(2012).Understanding Economic Growth In China And India: A Comparative Study Of Selected Issue. Singapore : World Scientific

Werner,J.M.(2021).Human Resource Development: Talent Development. New York : Cengage Learning 